\section{2-Phospha-4-silabicyclo[1.1.0]butane as a Reactive Intermediate ${ }^{* *}$}

\section{J. Chris Slootweg, Frans J. J. de Kanter, Marius Schakel, Andreas W. Ehlers, Barbara Gehrhus, Martin Lutz, Allison M. Mills, Anthony L. Spek, and \\ Koop Lammertsma*}

Bicyclo[1.1.0]butane remains a fascinating compound. Stretching of its central $\mathrm{C}-\mathrm{C} \sigma$-bond culminates in a planar singlet diradical transition structure for inversion, ${ }^{[1]}$ whereas stretching of the peripheral bonds leads to valence isomerization. ${ }^{[2]}$ Bridging heteroatoms affect both processes. They enable the coexistence of the puckered bicyclic and planar diyl structures, and have thereby sparked intensive studies dominated by recent discoveries of diphosphorus analogues. Niecke et al. synthesized a crystalline 2,4-diphosphacyclobutane-1,3-diyl $\mathbf{A}^{[3]}$ that isomerizes photolytically to 2,4-diphos-

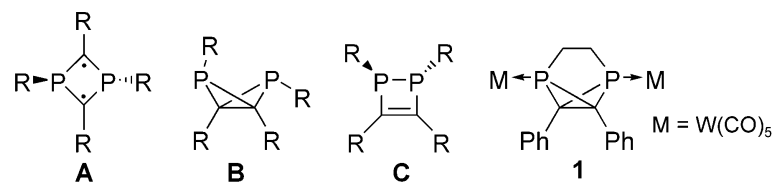

phabicyclo[1.1.0]butane $\mathbf{B}^{[4]}$ and thermally to 1,2-dihydro-1,2diphosphete $\mathbf{C} .^{[5]}$ A still more congested diyl $\mathbf{A}$ that does not isomerize was reported by Yoshifuji and co-workers. ${ }^{[6]}$ The group of Bertrand obtained both stable planar diyl and puckered forms for the isoelectronic 1,3-dibora-2,4-diphosphoniocyclobutanes. $^{[7]}$ 2,4-Diphosphabicyclo[1.1.0]butane is puckered when the phosphorus atoms are endo,endo substituted as in dihydro diphosphabenzvalene 1, which Mathey and co-workers obtained by an intramolecular phosphinidene addition to the $\mathrm{C}=\mathrm{C}$ bond of a $1 H$-phosphirene. ${ }^{[8]}$ Without geometrical constraints, such additions invariably lead to 1,2-

[*] J. C. Slootweg, Dr. F. J. J. de Kanter, Dr. M. Schakel, Dr. A. W. Ehlers, Prof. Dr. K. Lammertsma

Department of Organic and Inorganic Chemistry

Faculty of Sciences, Vrije Universiteit

De Boelelaan 1083, $1081 \mathrm{HV}$, Amsterdam (The Netherlands)

Fax: (+31) 20-444-7488

E-mail: lammert@chem.vu.nl

Dr. B. Gehrhus

Department of Chemistry

School of Life Science, University of Sussex

Brighton, BN1 9QJ (UK)

Dr. M. Lutz, Dr. A. M. Mills, Prof. Dr. A. L. Spek

Bijvoet Center for Biomolecular Research

Crystal and Structural Chemistry, Utrecht University

Padualaan 8, $3584 \mathrm{CH}$, Utrecht (The Netherlands).

[**; The Netherlands Organization for Scientific Research (NWO/CW) is acknowledged for partial support.

(घ) Supporting information for this article is available on the WWW under http://www.angewandte.org or from the author. diphosphetes of type $\mathbf{C}$ by isomerization or direct $\mathrm{C}-\mathrm{P}$ insertion. ${ }^{[9]}$

Data on 2,4-disilabicyclo[1.1.0]butanes ${ }^{[10]}$ is limited to two disilabenzvalenes ${ }^{[11]}$ and is absent for the corresponding planar diyls. Only a single 2-silabenzvalene is known, generated by photolysis of a silabenzene. ${ }^{[12]}$ For the synthesis of the 2,4-disila derivatives Ando et al. applied valence isomerization of bis(silirene) that involves an intramolecular silylene addition to the $\mathrm{C}=\mathrm{C}$ bond of a silirene. ${ }^{[11]}$ The use of stable silylenes might simplify this approach to a broader array of hetero derivatives, which we decided to explore for the unknown 2-phospha-4-silabicyclo[1.1.0]butanes 4.

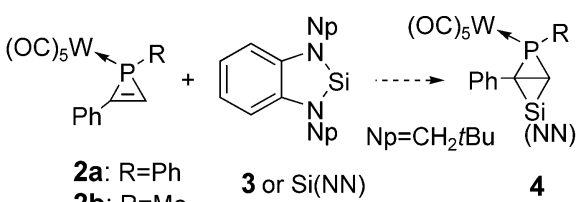

Reaction of silylene $\mathrm{Si}\left\{1,2-\left(\mathrm{NCH}_{2} t \mathrm{Bu}\right)_{2} \mathrm{C}_{6} \mathrm{H}_{4}\right\} \quad(\mathrm{Si}(\mathrm{NN})$; 3 ${ }^{[13]}$ with $1 H$-phosphirene $\mathbf{2 a}^{[14]}$ in $n$-hexane at room temperature results in red crystalline 2,3-dihydro-1,3-phosphasilete $5 \mathbf{a}$ instead of the desired 4 (Scheme 1). ${ }^{[15]}$ Evidently, two

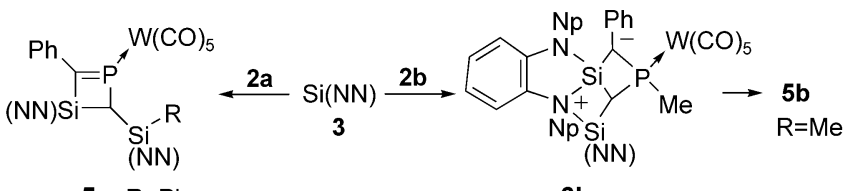

5a: $\mathrm{R}=\mathrm{Ph}$

$6 b$

Scheme 1. Synthesis of 2,3-dihydro-1,3-phosphasiletes 5.

silylenes are involved, one in forming the novel ring structure and the other as a substituent after transfer of a phenyl group. No intermediate was detected by ${ }^{31} \mathrm{P}$ NMR spectroscopy, either at low temperatures or with different stoichiometries of the reactants. The $\mathrm{W}(\mathrm{CO})_{5}$-complexed phosphaalkene part of $5 \mathbf{a}$ is characterized by the downfield absorptions at $\delta\left({ }^{31} \mathrm{P}\right)=$ $278.3 \mathrm{ppm} \quad\left({ }^{1} J(\mathrm{P}, \mathrm{W})=254.0 \mathrm{~Hz}\right) \quad$ and $\quad \delta\left({ }^{13} \mathrm{C}\right)=197.3 \mathrm{ppm}$ $\left({ }^{1} J(\mathrm{C}, \mathrm{P})=3.5 \mathrm{~Hz}\right)$. A single-crystal X-ray analysis confirmed the structure of 5a (Figure 1). ${ }^{[16]}$ Its four-membered ring deviates from planarity owing to steric congestion, which is reflected in the torsion angle of $11.6(2)^{\circ}$ for $\mathrm{C} 1-\mathrm{P} 1-\mathrm{C} 2-\mathrm{Si} 1$. The $\mathrm{P} 1-\mathrm{C} 1$ and $\mathrm{P} 1-\mathrm{C} 2$ bond lengths (1.689(4) and 1.835(4) $\AA$, respectively) are normal, but the short Si1-C1 bond (1.841(5) A) suggests some delocalization of charge.

To lower the migratory aptitude of the phosphorus substituent, we replaced the phenyl for a methyl group and used $1 H$-phosphirene $\mathbf{2} \mathbf{b}^{[14]}$ instead of $\mathbf{2} \mathbf{a}$ for the addition of silylene 3. This had the desired effect, giving the crystalline zwitterion $\mathbf{6 b}(68 \%)$, which only rearranged at elevated temperatures $\left(75^{\circ} \mathrm{C}, 2 \mathrm{~h}\right)$ to 2,3-dihydro-1,3-phosphasilete $\mathbf{5 b}$ (Scheme 1). The molecular structure of $\mathbf{6 b}$ (Figure 2, ${ }^{[16]}$ the crystal contains two independent molecules with similar geometries) shows a unique fused tricyclic ring structure which is retained in solution $\left(\delta\left({ }^{31} \mathrm{P}\right)=-6.8 \mathrm{ppm}\left({ }^{1} J(\mathrm{P}, \mathrm{W})=\right.\right.$ 


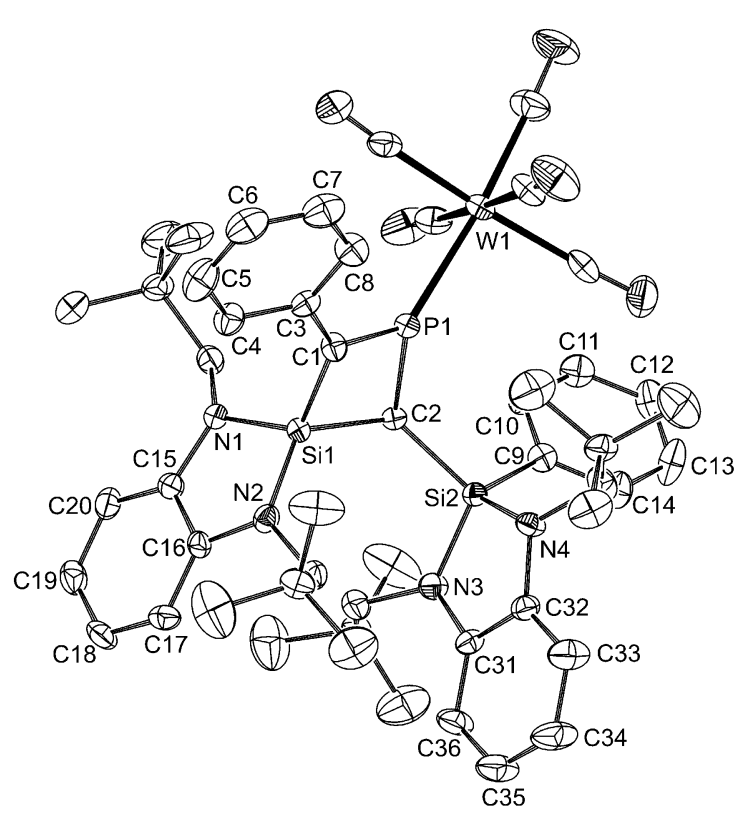

Figure 1. Structure of $\mathbf{5} \mathbf{a}$ in the crystal (displacement ellipsoids drawn at the $50 \%$ probability level; hydrogen atoms and the hexane solvent molecule are omitted for clarity). Selected bond lengths $[\AA \AA]$, angles $\left[{ }^{\circ}\right]$, and torsion angles [ ${ }^{\circ}$ ]: $\mathrm{W} 1-\mathrm{P} 12.4492(11), \mathrm{P} 1-\mathrm{C} 11.689(4), \mathrm{P} 1-\mathrm{C} 2$ 1.835(4), Si1-C1 1.841(5), Si1-C2 1.908(4); C1-P1-C2 92.9(2), P1-C2Sil 86.13(17), C1-Si1-C2 85.96(18), P1-C1-Si1 92.7(2); C1-P1-C2-Si1 $11.6(2)$.

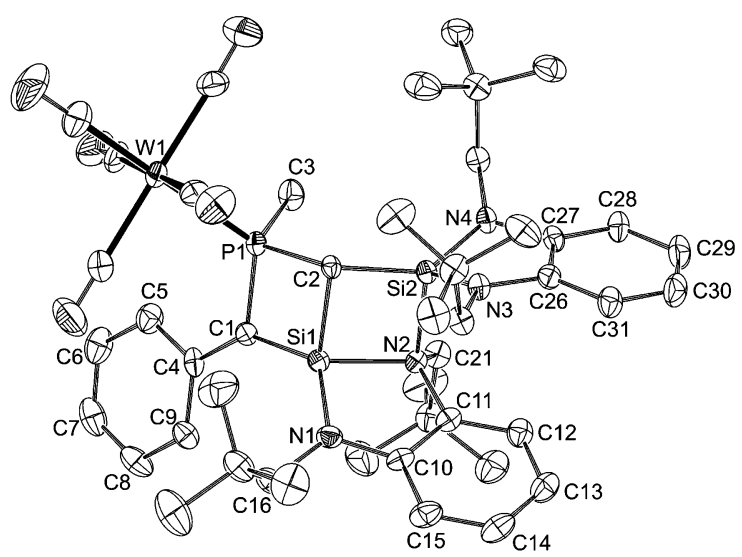

Figure 2. Structure of $\mathbf{6} \mathbf{b}$ in the crystal, one of the two crystallographically independent molecules is shown (displacement ellipsoids drawn at the $50 \%$ probability level; hydrogen atoms omitted for clarity). Selected bond lengths $[\AA \AA]$, angles $\left[{ }^{\circ}\right]$, and torsion angles $\left[{ }^{\circ}\right]$ : W1-P1 2.5363(12), P1-C1 1.793(4), P1-C2 1.863(4), Si1-N1 1.725(4), Si1-N2 $1.923(4)$, Si1-C1 1.750(4), Si1-C2 1.906(4), Si2-N2 1.933(4), Si2-N3 1.710(4), Si2-N4 1.705(4), Si2-C2 1.828(4), N1-C10 1.409(6), N1$\mathrm{C} 161.471(6), \mathrm{N} 2-\mathrm{C} 111.471(5), \mathrm{N} 2-\mathrm{C} 211.510(5), \mathrm{Cl}-\mathrm{C} 41.455(6)$; C1-P1-C2 90.79(19), P1-C2-Si1 85.70(18), C1-Si1-C2 90.70(19), P1-C1Sil 92.7(2); C2-P1-Cl-Si1 -2.4(2), P1-C1-C4-C5 8.2(8).

$240.0 \mathrm{~Hz}), \quad \delta\left({ }^{29} \mathrm{Si}\right)=-11.2 \quad\left({ }^{2} J(\mathrm{Si}, \mathrm{P})=17.2 \mathrm{~Hz}, \quad \mathrm{SiNN}\right) \quad$ and $-33.4 \mathrm{ppm} \quad\left({ }^{2} J(\mathrm{Si}, \mathrm{P})=18.4 \mathrm{~Hz}, \quad \mathrm{SiNN}^{+}\right)$. The negatively charged $\mathrm{C} 1$ is in a planar environment and is surrounded by

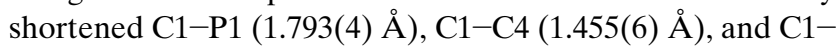
Si1 (1.750(4) A) bonds that can be attributed to negative hyperconjugation, which is supported by the shielding of Si1 $\left(\delta\left({ }^{29} \mathrm{Si}\right)=-33.4 \mathrm{ppm}\right) \cdot{ }^{[17]}$ Furthermore, the cationic $\mathrm{N} 2$ lengthens the N2-Si and N2-C bonds. ${ }^{[18]}$

We assume that the reaction starts by addition of the silylene to the $\mathrm{C}=\mathrm{C}$ bond of the phosphirene to give 2phospha-4-silabicyclo[1.1.0]butane $\mathbf{4 b}$ as a transient intermediate, followed by attack of a second silylene to the bridgehead carbon atom in a manner analogous to the reaction of nucleophiles with bicyclo[1.1.0]butane (Scheme 2). ${ }^{[19]}$ The resulting $\mathbf{7 b}$ carries a silylium cation,

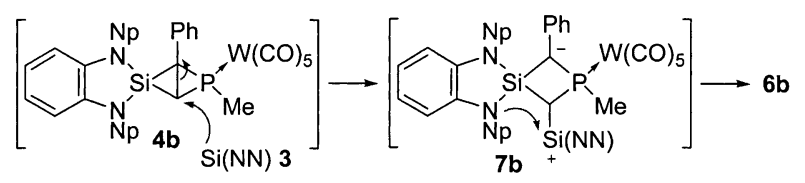

Scheme 2. Mechanism for the formation of $\mathbf{6 b}$.

which requires stabilization ${ }^{[20]}$ by coordination with the lone pair of electrons of a nearby nitrogen atom. ${ }^{[21]}$ This hypothesis was tested with SCS-MP2/6-311 $+\mathrm{G}^{* *}$ energy calculations on B3LYP6-31G* optimized model structures (labeled B), ${ }^{[22]}$ which are devoid of $\mathrm{W}(\mathrm{CO})_{5}$, carry $\mathrm{H}$ instead of $\mathrm{Np}$ substituents, and have the nitrogen atoms linked by ethylene instead of phenyl groups. This simplification is validated by the similarity in optimized structures between $\mathbf{4 B}$ and that containing the $\mathrm{Np}$ and $\mathrm{W}(\mathrm{CO})_{5}$ groups. Formation of $\mathbf{4 B}$ from the reactants $\mathrm{C}_{2} \mathrm{H}_{4} \mathrm{~N}_{2} \mathrm{Si}$ and $\mathrm{C}_{3} \mathrm{H}_{5} \mathrm{P}$ is exothermic by $17.5 \mathrm{kcal}$ $\mathrm{mol}^{-1}$ with an additional $8.5 \mathrm{kcal} \mathrm{mol}^{-1}$ for the addition of a second silylene to give $\mathbf{7 B}$ (Figure 3). Lewis base stabilization

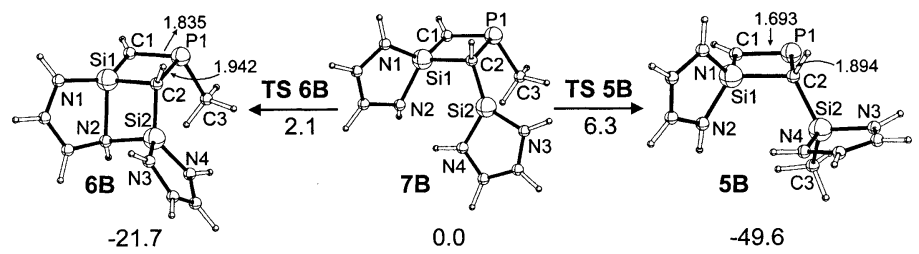

Figure 3. Relative SCS-MP2/6-311+C**//B3YLP/6-31G* energies (in kcal$\mathrm{mol}^{-1}$ ) for the rearrangement of $\mathbf{6 B}$ to the thermodynamically more stable $5 \mathbf{B}$ with selected bond lengths $[\AA]$.

of the silylium cation gives the kinetically favored zwitterion 6B $\left(\Delta E=21.7, \Delta E^{*}=2.1 \mathrm{kcalmol}^{-1}\right)$, whereas a 1,3-methyl shift from phosphorus to silicon results in the thermodynamically favored phosphasilete $\mathbf{5 B}\left(\Delta E=49.6, \Delta E^{\neq}=6.3 \mathrm{kcal}\right.$ $\mathrm{mol}^{-1}$ ). Such 1,3-shifts to an electron-deficient silicon are very rare for both the methyl and phenyl groups. ${ }^{[23,24]}$

To reduce the attractiveness of the transient 2-phospha-4silabicyclo[1.1.0]butane for attack by a second silylene, a methyl group was introduced at the bridgehead position by treating $1 H$-phosphirene $2 \mathbf{c}^{[14]}$ with $\mathbf{3}$. This had the desired effect, but mainly valence isomerization occurred to the isomeric 1,2-dihydro-1,2-phosphasiletes $\mathbf{8 a}$ and $\mathbf{8 b},{ }^{[25]}$ together with the formation of some $\mathbf{5 c}(5: 2: 2)$, because of the elevated temperatures $\left(80^{\circ} \mathrm{C}, 13 \mathrm{~h}\right)$ required for the reaction to take place (Scheme 3 ). After fractional crystallization, 8 a could be obtained as a yellow solid for which only single resonances were observed at $\delta\left({ }^{31} \mathrm{P}\right)=15.2 \mathrm{ppm}$ 


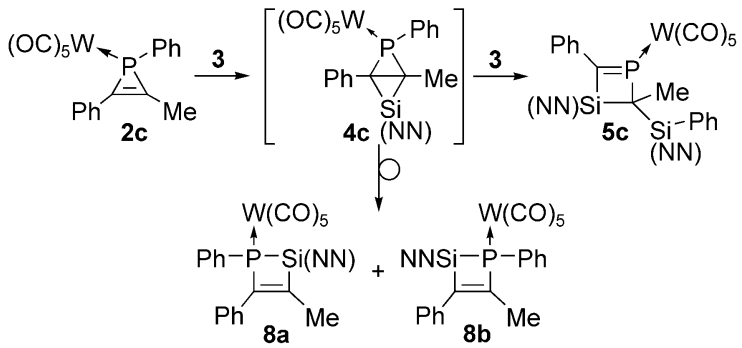

Scheme 3. Isomerization of $4 \mathrm{c}$.

$\left({ }^{1} J(\mathrm{P}, \mathrm{W})=205.0 \mathrm{~Hz}\right) \quad$ and $\quad \delta\left({ }^{29} \mathrm{Si}\right)=-17.1 \mathrm{ppm} \quad\left({ }^{1} J(\mathrm{Si}, \mathrm{P})=\right.$ $45.6 \mathrm{~Hz})$ confirming the stoichiometry of the reaction. The structure of $\mathbf{8 a}$ was established unequivocally by a singlecrystal X-ray structural analysis (Figure 4), ${ }^{[16]}$ which shows

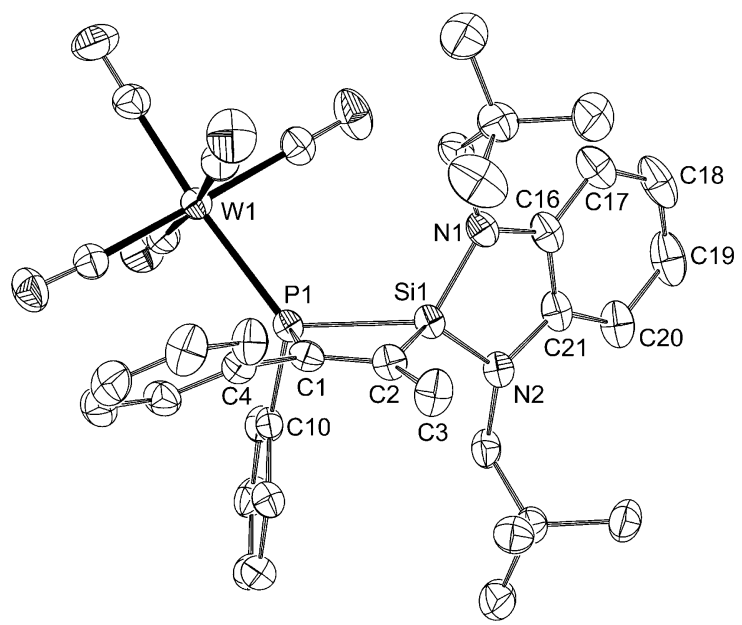

Figure 4. Structure of $\mathbf{8} \mathbf{a}$ in the crystal (displacement ellipsoids drawn at the $50 \%$ probability level; hydrogen atoms are omitted for clarity). Selected bond lengths $[\AA]$, angles $\left[{ }^{\circ}\right]$, and torsion angles $\left[{ }^{\circ}\right]$ : W1-P1 2.5269(6), P1-Si1 2.3074(8), P1-C1 1.854(2), P1-C10 1.841(2), Si1N1 1.726(2), Si1-N2 1.7249(19), Si1-C2 1.863(2), C1-C2 1.360(3), C1-C4 1.489(3), C2-C3 1.507(3); C1-P1-Si1 73.30(7), P1-Si1-C2 76.89(7); P1-C1-C2-Si1 7.46(17).

that the four-membered ring is nearly planar with a torsion angle of $7.46(17)^{\circ}$ for $\mathrm{P} 1-\mathrm{C} 1-\mathrm{C} 2-\mathrm{Si} 1$ and that the $\mathrm{P} 1-\mathrm{Si} 1$ bond $(2.3074(8) \AA)$ is slightly elongated owing to steric congestion.

SCS-MP2/6-311 + $\mathrm{G}^{* *}$ calculations on B3LYP/6-31G* model structures containing carbon substituents ${ }^{[22]}$ show that intermediate 2-phospha-4-silabicyclo[1.1.0]butane 4C can isomerize to the thermodynamically preferred 1,2-dihydro1,2-phosphasiletes $\mathbf{8 A}$ and $\mathbf{8 B}$ with barriers of only 21.3 and $21.6 \mathrm{kcal} \mathrm{mol}^{-1}$, respectively. This similarity in $\Delta E^{\neq}$values is reflected in the two experimentally observed isomers. The valence isomerization of $\mathbf{4 C}$ to $\mathbf{8}$ is symmetry-allowed and can be described as a $[\sigma 2 s+\sigma 2 a]$ process. ${ }^{[26]}$ Such a pathway is unprecedented for the analogous isomerization of bicyclo[1.1.0]butane, for which s-trans-1,3-butadiene is the favored product.

In conclusion, thermally stable silylene 3 reacts with $1 H$ phosphirenes 2 to give the first isolated 2,3-dihydro-1,3- phosphasiletes 5, zwitterion $\mathbf{6 b}$, and 1,2-dihydro-1,2-phosphasiletes $\mathbf{8}$ with the novel 2-phospha-4-silabicyclo[1.1.0]butanes 4 being a reactive intermediate in the reaction, the course of which can be tuned by changing the substituents.

\section{Experimental Section}

5a: Complex 2a ${ }^{[14]}(38.6 \mathrm{mg}, 72.3 \mu \mathrm{mol})$ in $n$-hexane $(5 \mathrm{~mL})$ was added slowly to a solution of $\mathbf{3}^{[13]}(39.7 \mathrm{mg}, 144.6 \mu \mathrm{mol})$ in $n$-hexane $(2 \mathrm{~mL})$ at $-50^{\circ} \mathrm{C}$, warmed to ambient temperature, and stirred for $16 \mathrm{~h}$. Filtration, concentration, and cooling at $-20^{\circ} \mathrm{C}$ affording red crystals of 5a $(56 \mathrm{mg}, 66 \%)$ : m.p. $245^{\circ} \mathrm{C}$ (decomp.); ${ }^{29} \mathrm{Si} \mathrm{NMR}$ $\left(79.5 \mathrm{MHz}, \quad \mathrm{C}_{6} \mathrm{D}_{6}\right): \quad \delta=-5.1 \quad\left(\mathrm{~d}, \quad{ }^{2} J(\mathrm{Si}, \mathrm{P})=6.9 \mathrm{~Hz} ; \quad \mathrm{Ph}-\mathrm{SiNN}\right)$, $-13.5 \mathrm{ppm}\left(\mathrm{d},{ }^{2} \mathrm{~J}(\mathrm{Si}, \mathrm{P})=31.8 \mathrm{~Hz} ; \mathrm{SiNN}\right) ;{ }^{31} \mathrm{P}\left\{{ }^{1} \mathrm{H}\right\} \mathrm{NMR}(101.3 \mathrm{MHz}$, $\left.\mathrm{CDCl}_{3}\right): \delta=278.3 \mathrm{ppm}\left({ }^{1} J(\mathrm{P}, \mathrm{W})=254.0 \mathrm{~Hz}\right) ; \mathrm{HRMS}(\mathrm{EI}, 70 \mathrm{eV}): \mathrm{m} / z$ (\%): 1082 (2) $\left[M^{+}\right]$; calcd for $\mathrm{C}_{51} \mathrm{H}_{63} \mathrm{O}_{5} \mathrm{~N}_{4} \mathrm{Si}_{2} \mathrm{PW}: 1082.35840$; found: 1082.35376.

5b: Complex $\mathbf{2 b}^{[14]}(12.3 \mathrm{mg}, 26.0 \mu \mathrm{mol})$ and $\mathbf{3}(14.3 \mathrm{mg}$, $52.1 \mu \mathrm{mol})$ were heated at $75^{\circ} \mathrm{C}$ for $2 \mathrm{~h}$ in $\mathrm{C}_{6} \mathrm{D}_{6}(0.5 \mathrm{~mL})$. Evaporation to dryness, extraction into $n$-hexane, and subsequent filtration and cooling at $-20^{\circ} \mathrm{C}$ gave red crystals of $\mathbf{5 b}(15 \mathrm{mg}, 57 \%)$ : m.p. $150{ }^{\circ} \mathrm{C}$ (decomp.) ${ }^{29} \mathrm{Si} \mathrm{NMR}\left(79.5 \mathrm{MHz}, \mathrm{C}_{6} \mathrm{D}_{6}\right): \delta=4.8\left(\mathrm{~d},{ }^{2} J(\mathrm{Si}, \mathrm{P})=4.2 \mathrm{~Hz}\right.$; Me-SiNN), $-13.8 \mathrm{ppm}\left(\mathrm{d},{ }^{2} J(\mathrm{Si}, \mathrm{P})=33.2 \mathrm{~Hz} ; \mathrm{SiNN}\right) ;{ }^{31} \mathrm{P}\left\{{ }^{1} \mathrm{H}\right\} \mathrm{NMR}$ $\left(101.3 \mathrm{MHz}, \mathrm{C}_{6} \mathrm{D}_{6}\right): \delta=276.6 \mathrm{ppm}\left({ }^{1} J(\mathrm{P}, \mathrm{W})=246.1 \mathrm{~Hz}\right) ; \mathrm{HRMS}(\mathrm{EI}$, $70 \mathrm{eV}): \mathrm{m} / z(\%): 1020(5)\left[M^{+}\right]$; calcd for $\mathrm{C}_{46} \mathrm{H}_{61} \mathrm{O}_{5} \mathrm{~N}_{4} \mathrm{Si}_{2} \mathrm{PW}$ : 1020.34277; found: 1020.3391

6b: Complex 2 b $(20.4 \mathrm{mg}, 43.2 \mu \mathrm{mol})$ in $n$-hexane $(5 \mathrm{~mL})$ was added to a solution of $\mathbf{3}(23.7 \mathrm{mg}, 86.3 \mu \mathrm{mol})$ in $n$-hexane $(2 \mathrm{~mL})$ at ambient temperature and stirred for $2 \mathrm{~h}$. Concentration and cooling at $0{ }^{\circ} \mathrm{C}$ affording yellow crystals of $6 \mathbf{b}(30 \mathrm{mg}, 68 \%)$ : m.p. $149^{\circ} \mathrm{C}$ (decomp.); ${ }^{29} \mathrm{Si} \mathrm{NMR}\left(79.5 \mathrm{MHz}, \mathrm{C}_{6} \mathrm{D}_{6}\right): \delta=-33.4\left(\mathrm{~d},{ }^{2} J(\mathrm{Si}, \mathrm{P})=\right.$ $\left.18.4 \mathrm{~Hz} ; \quad \mathrm{SiNN}^{+}\right), \quad-11.2 \mathrm{ppm} \quad\left(\mathrm{d}, \quad{ }^{2} J(\mathrm{Si}, \mathrm{P})=17.2 \mathrm{~Hz} ; \quad \mathrm{SiNN}\right)$; ${ }^{31} \mathrm{P}\left\{{ }^{1} \mathrm{H}\right\}$ NMR $\left(101.3 \mathrm{MHz}, \mathrm{C}_{6} \mathrm{D}_{6}\right): \delta=-6.8 \mathrm{ppm}\left({ }^{1} J(\mathrm{P}, \mathrm{W})=240.0 \mathrm{~Hz}\right)$.

8: Complex 2 $\mathbf{c}^{[14]}(44.9 \mathrm{mg}, 81.9 \mu \mathrm{mol})$ and $\mathbf{3}(33.7 \mathrm{mg}$, $122.8 \mu \mathrm{mol})$ were heated at $80^{\circ} \mathrm{C}$ for $13 \mathrm{~h}$ in $\mathrm{C}_{6} \mathrm{D}_{6}(0.5 \mathrm{~mL})$. ${ }^{31} \mathrm{P}\left\{{ }^{1} \mathrm{H}\right\}$ NMR $\left(101.3 \mathrm{MHz}, \mathrm{C}_{6} \mathrm{D}_{6}\right): \delta=12.0\left({ }^{1} J(\mathrm{P}, \mathrm{W})=198.5 \mathrm{~Hz}, 19 \%\right.$ yield of $\mathbf{8 b}$ by NMR spectroscopy), $15.2\left({ }^{1} J(\mathrm{P}, \mathrm{W})=205.6 \mathrm{~Hz}, 50 \%\right.$ yield of $\mathbf{8} \mathbf{a}$ by NMR spectroscopy), $308.1 \mathrm{ppm}$ (br s, $19.5 \%$ yield of $\mathbf{5 c}$ by NMR spectroscopy). Evaporation to dryness, extraction into $n$ hexane, and subsequent cooling at $-80^{\circ} \mathrm{C}$ gave yellow crystals of $\mathbf{8 a}$ (30 mg, $45 \%$ ): m.p. $157^{\circ} \mathrm{C}$ (decomp.); ${ }^{29} \mathrm{Si}$ NMR (79.5 MHz, $\mathrm{C}_{6} \mathrm{D}_{6}$ ): $\delta=-17.1 \mathrm{ppm} \quad\left(\mathrm{d}, \quad{ }^{1} J(\mathrm{Si}, \mathrm{P})=45.6 \mathrm{~Hz} ; \quad \mathrm{SiNN}\right) ; \quad{ }^{31} \mathrm{P}\left\{{ }^{1} \mathrm{H}\right\} \mathrm{NMR}$ $\left(101.3 \mathrm{MHz}, \mathrm{C}_{6} \mathrm{D}_{6}\right): \delta=15.2 \mathrm{ppm}\left({ }^{1} J(\mathrm{P}, \mathrm{W})=205.0 \mathrm{~Hz}\right)$; HRMS $(\mathrm{EI}$, $70 \mathrm{eV}): m / z(\%): 822(80)\left[M^{+}\right]$; calcd for $\mathrm{C}_{36} \mathrm{H}_{39} \mathrm{O}_{5} \mathrm{~N}_{2} \mathrm{SiPW}: 822.1876$; found: 822.1880. 5c: MS (EI, $70 \mathrm{eV}): m / z(\%): 1096(30)\left[M^{+}\right]$.

Received: March 4, 2004 [Z54183]

Keywords: phosphorus heterocycles - reaction mechanisms . reactive intermediates . substituent effects - valence isomerization

[1] K. A. Nguyen, M. S. Gordon, J. A. Boatz, J. Am. Chem. Soc. 1994, 116, $9241-9249$.

[2] K. A. Nguyen, M. S. Gordon, J. Am. Chem. Soc. 1995, 117, 3835 3847.

[3] E. Niecke, A. Fuchs, F. Baumeister, M. Nieger, W. W. Schoeller, Angew. Chem. 1995, 107, 640-642; Angew. Chem. Int. Ed. Engl. 1995, 34, 555-557.

[4] E. Niecke, A. Fuchs, M. Nieger, Angew. Chem. 1999, 111, 3213 3216; Angew. Chem. Int. Ed. 1999, 38, 3028-3031.

[5] O. Schmidt, A. Fuchs, D. Gudat, M. Nieger, W. Hoffbauer, E. Niecke, W. W. Schoeller, Angew. Chem. 1998, 110, 995-998; Angew. Chem. Int. Ed. 1998, 37, 949-952. 
[6] H. Sugiyama, S. Ito, M. Yoshifuji, Angew. Chem. 2003, 115, 3932-3934; Angew. Chem. Int. Ed. 2003, 42, 3802-3804.

[7] a) D. Scheschkewitz, H. Amii, H. Gornitzka, W. W. Schoeller, D. Bourissou, G. Bertrand, Science 2002, 295, 1880-1881; b) D. Scheschkewitz, H. Amii, H. Gornitzka, W. W. Schoeller, D. Bourissou, G. Bertrand, Angew. Chem. 2004, 116, 595-597; Angew. Chem. Int. Ed. 2004, 43, 585-587.

[8] M. White, L. Ricard, F. Mathey, Organometallics 2003, 22, 4825 4828.

[9] a) N. H. Tran Huy, L. Ricard, F. Mathey, Organometallics 1997 16, 4501-4504; b) B. Wang, K. A. Ngyen, G. N. Srinivas, C. L. Watkins, S. Menzer, A. L. Spek, K. Lammertsma, Organometallics 1999, 18, 796-799.

[10] Only one $\mathrm{Si}_{2} \mathrm{C}_{2}$-ring is known: G. Fritz, S. Wartenessian, E. Matern, W. Hömle, H. G. Von Schnering, Z. Anorg. Allg. Chem. 1981, 475, 87-108.

[11] a) W. Ando, T. Shiba, T. Hidaka, K. Morihashi, O. Kikuchi, $J$. Am. Chem. Soc. 1997, 119, 3629-3630; b) Y. Kabe, K. Ohkubo, H. Ishikawa, W. Ando, J. Am. Chem. Soc. 2000, 122, 3775-3776.

[12] K. Wakita, N. Tokitoh, R. Okazaki, N. Takagi, S. Nagase, J. Am. Chem. Soc. 2000, 122, 5648-5649.

[13] B. Gehrhus, M. F. Lappert, J. Heinicke, R. Boese, D. Bläser, J. Chem. Soc. Chem. Commun. 1995, 1931-1932.

[14] A. Marinetti, F. Mathey, Organometallics 1984, 3, 456-461. Synthesis of $\mathbf{2 b}$ and $\mathbf{2 c}$ was performed in analogy to $\mathbf{2 a}$; see Supporting Information.

[15] So far, only one $1 \lambda^{3}-1,3-$ phosphasilete was mentioned: M. Driess, H. Pritzkow, Phosphorus Sulfur Silicon Relat. Elem. 1993, 76 , 57-60.

[16] Crystal structure determinations: X-ray intensities were measured on a Nonius KappaCCD diffractometer with rotating anode $(\lambda=0.71073 \AA)$ at a temperature of $150(2) \mathrm{K}$. The structures were refined with SHELXL97 $7^{[27]}$ against $\mathrm{F}^{2}$ of all reflections. Illustrations, structure calculations and checking was performed with the PLATON package. ${ }^{[28]}$ 5a $\left(\mathrm{C}_{51} \mathrm{H}_{63} \mathrm{~N}_{4} \mathrm{O}_{5} \mathrm{P}\right.$ $\left.\mathrm{Si}_{2} \mathrm{~W} \cdot 0.6 \mathrm{C}_{6} \mathrm{H}_{14}\right): M_{\mathrm{w}}=1134.76$, red block, $0.06 \times 0.18 \times 0.21 \mathrm{~mm}^{3}$, monoclinic, $P 2_{1}$ (No. 4), $a=10.5532(1), b=16.0049(2), c=$ 17.2900(2) $\AA, \quad \beta=100.5233(5), \quad V=2871.21(6) \AA^{3}, \quad Z=2, \rho=$ $1.313 \mathrm{~g} \mathrm{~cm}^{-3} ; 51129$ measured reflections, 13052 unique reflections $\left(R_{\text {int }}=0.050\right)$; structure solution with automated Patterson methods $;{ }^{[29]} 643$ refined parameters, 46 restraints; $R 1 / w R 2[I>$ $2 \sigma(I)]: 0.0338 / 0.0755, R 1 / w R 2$ (all reflections) $=0.0472 / 0.0794$; $\mathrm{GoF}=1.072$; Flack $\times$ parameter: $-0.024(4) .6 \mathbf{b}\left(\mathrm{C}_{46} \mathrm{H}_{61} \mathrm{~N}_{4} \mathrm{O}_{5} \mathrm{P}-\right.$ $\left.\mathrm{Si}_{2} \mathrm{~W}\right): M_{\mathrm{w}}=1020.99$, yellow block, $0.18 \times 0.24 \times 0.30 \mathrm{~mm}^{3}$, triclinic, $\quad P \overline{1} \quad$ (No. 2), $\quad a=10.6476(3), \quad b=21.2390(8), \quad c=$ 22.6862(5) $\AA, \quad \alpha=74.495(2), \quad \beta=89.5698(19), \quad \gamma=82.814(3)^{\circ}$, $V=4903.0(3) \AA^{3}, Z=4, \rho=1.383 \mathrm{~g} \mathrm{~cm}^{-3}$. The crystal appeared to be non-merohedrally twinned with a $180^{\circ}$ rotation about $u v w=[100]$ as twin operation. The intensity data were evaluated with EvalCCD ${ }^{[30]}$ taking this twin relation into account; 55937 measured reflections, 22336 unique reflections $\left(R_{\text {int }}=0.058\right)$; sructure solution with direct methods $;{ }^{[31]} 1064$ refined parameters, 388 restraints; bond lengths and angles of the two independent molecules were restrained to be the same; $R 1 /$ $w R 2[I>2 \sigma(I)]: 0.0499 / 0.1070, R 1 / w R 2$ (all reflections) $=0.0767 /$ 0.1216 ; $\mathrm{GoF}=1.128$; the refinement ${ }^{[24]}$ of the twin fraction resulted in 0.794(1):0.206. 8a $\left(\mathrm{C}_{36} \mathrm{H}_{39} \mathrm{~N}_{2} \mathrm{O}_{5} \mathrm{PSiW}\right): M_{\mathrm{w}}=822.60$, yellow plate, $0.06 \times 0.36 \times 0.42 \mathrm{~mm}^{3}$, monoclinic, $P 2_{1} / \mathrm{c}$ (No. 14 ), $a=19.1665(1), \quad b=10.6482(1), \quad c=20.5181(1) \AA, \quad \beta=$ $119.8343(4)^{\circ}, V=3632.53(5) \AA^{3}, Z=4, \rho=1.504 \mathrm{~g} \mathrm{~cm}^{-3} ; 58693$ measured reflections, 8329 unique reflections $\left(R_{\text {int }}=0.046\right)$; structure solution with automated Patterson methods; ${ }^{[29]} 422$ refined parameters, no restraints; $R 1 / w R 2[I>2 \sigma(I)]: 0.0204 /$ $0.0455, R 1 / w R 2$ (all reflections) $=0.0289 / 0.0488 ; \mathrm{GoF}=1.038$. CCDC-216769 (5a), -216770 (6b), and -232111 (8a) contain the supplementary crystallographic data for this paper. These data can be obtained free of charge via www.ccdc.cam.ac.uk/conts/ retrieving.html (or from the Cambridge Crystallographic Data Centre, 12, Union Road, Cambridge CB21EZ, UK; fax: (+44)1223-336-033; or deposit@ccdc.cam.ac.uk).

[17] M. Sebastian, M. Nieger, D. Szieberth, L. Nyulászi, E. Niecke, Angew. Chem. 2004, 116, 647-651; Angew. Chem. Int. Ed. 2004, 43, 637-641.

[18] R. Bettenhausen, W. Milius, W. Schnick, Chem. Eur. J. 1997, 3, $1337-1341$

[19] S. Hoz in The Chemistry of the Cyclopropyl Group, Part 2 (Ed.: Z. Rappoport), Wiley, New York, 1987, Chapter 19.

[20] K. -C. Kim, C. A. Reed, D. W. Elliott, L. J. Mueller, F. Tham, L. Lin, J. B. Lambert, Science 2002, 297, 825-827.

[21] R. Corriu, G. Lanneau, C. Priou, Angew. Chem. 1991, 103, 1153 1155; Angew. Chem. Int. Ed. Engl. 1991, 30, 1130-1132.

[22] a) Gaussian 98 (Revision A.7), M. J. Frisch, G. W. Trucks, H. B. Schlegel, G. E. Scuseria, M. A. Robb, J. R. Cheeseman, V. G. Zakrzewski, J. A. Montgomery, R. E. Stratmann, J. C. Burant, S. Dapprich, J. M. Millam, A. D. Daniels, K. N. Kudin, M. C. Strain, O. Farkas, J. Tomasi, V. Barone, M. Cossi, R. Cammi, B. Mennucci, C. Pomelli, C. Adamo, S. Clifford, J. Ochterski, G. A. Petersson, P. Y. Ayala, Q. Cui, K. Morokuma, D. K. Malick, A. D. Rabuck, K. Raghavachari, J. B. Foresman, J. Cioslowski, J. V. Ortiz, B. B. Stefanov, G. Liu, A. Liashenko, P. Piskorz, I. Komaromi, R. Gomperts, R. L. Martin, D. J. Fox, T. Keith, M. A. Al-Laham, C. Y. Peng, A. Nanayakkara, C. Gonzalez, M. Challacombe, P. M. W. Gill, B. G. Johnson, W. Chen, M. W. Wong, J. L. Andres, M. Head-Gordon, E. S. Replogle, J. A. Pople, Gaussian, Inc., Pittsburgh, PA, 1998; b) A. D. Becke, Phys. Rev. A 1988, 38, 3098-3100; c) C. Lee, W. Yang, R. G. Parr, Phys. Rev. B 1988, 37, 785-789; d) S. Grimme, J. Chem. Phys, 2003, 118, 9095-9102; see Supporting Information.

[23] a) K. Ueno, K. Nakano, H. Ogino, Chem. Lett. 1996, 459-460, and references therein; b) K. Ueno, M. Sakai, H. Ogino, Organometallics 1998, 17, 2138-2140.

[24] C. Eaborn, A. Kowalewska, W. Stanczyk, J. Organomet. Chem. 1998, 560, 41-46, and references therein.

[25] Only one other synthesis of 1,2-dihydro-1,2-phosphasiletes was reported: a) S. Haber, R. Boese, M. Regitz, Angew. Chem. 1990, 102, 1523-1525; Angew. Chem. Int. Ed. Engl. 1990, 29, 14361438 ; b) S. Haber, M. Schmitz, U. Bergsträßer, J. Hoffmann, M. Regitz, Chem. Eur. J. 1999, 5, 1581-1589.

[26] J. C. Slootweg, A. W. Ehlers, K. Lammertsma, Phosphorus Sulfur Silicon Relat. Elem. 2004, 179, 803-807.

[27] G. M. Sheldrick, SHELXL-97, Program for crystal structure refinement, University of Göttingen, Germany, 1997.

[28] A. L. Spek, J. Appl. Crystallogr. 2003, 36, 7-13.

[29] P. T. Beurskens, G. Admiraal, G. Beurskens, W. P. Bosman, S. Garcia-Granda, R. O. Gould, J. M. M. Smits, C. Smykalla, The DIRDIF99 program system, Technical Report of the Crystallography Laboratory, University of Nijmegen, The Netherlands, 1999.

[30] A. J. M. Duisenberg, L. M. J. Kroon-Batenburg, A. M. M. Schreurs, J. Appl. Crystallogr. 2003, 36, 220-229.

[31] G. M. Sheldrick, SHELXS-97, Program for crystal structure solution, University of Göttingen, Germany, 1997. 